\title{
The Revolution is Over, Forget It: To the 30th Anniversary of the Russian Federation
}

\author{
Yu.A. Nisnevich \\ National Research University Higher School of Economics, Moscow, Russian Federation
}

\begin{abstract}
After the collapse of the Soviet Union, the power in post-Soviet Russia was seized by the leaders of the democratic movement - "first wave democrats", and the more progressive Soviet nomenclature. As a result of the miscalculations made by the leaders of the democratic movement, the representatives of the Soviet nomenclature soon started displacing the "first wave democrats" and the reformers of the "Gaidar call" from the Russian governmental bodies in order to gain full control over the governance in the country. This appeared to be a manifestation of the more general and fundamental process, where the Russian nomenclature separated from the democratic movement, emerging as a new ruling stratum - the immediate heir to the Soviet nomenclature. The turning point, which accelerated the separation and the retreat of the Russian nomenclature from liberal and democratic principles of the country's modernization, was the beginning of the Chechen tragedy in 1994. Not only did the Chechen events separate the Russian nomenclature and the democratic movement but also split the democratic movement itself. The goal of the article is to examine the transformation of the relationship between the democratic movement and the soviet and, later on, Russian nomenclature during the revolutionary changes of the early 1990s.
\end{abstract}

Keywords: revolutionary transformations, post-Soviet Russia, democratic movement, nomenclature, Chechen fault

For citation: Nisnevich, Yu.A. (2021). The revolution is over, forget it: To the 30th anniversary of the Russian Federation. RUDN Journal of Political Science, 23(4), 545-559. DOI: 10.22363/23131438-2021-23-4-545-559

\section{Революция закончена, забудьте: к 30-летию Российской Федерации}

\section{Ю.А. Нисневич}

Национальный исследовательский университет «Высшая школа экономики», Москва, Российская Федерация

Аннотация. В статье рассматривается процесс трансформации взаимоотношений между демократическим движением и сначала советской, а затем нарождающейся российской номенклатурой в период революционных преобразований начала 90-х годов XX века. После

(C) Nisnevich Yu.A., 2021

This work is licensed under a Creative Commons Attribution 4.0 International License https://creativecommons.org/licenses/by/4.0/ 
распада СССР к власти в постсоветской России пришел конгломерат лидеров демократического движения - «демократов первой волны» и представителей прогрессистки настроенной части советской партийно-хозяйственной номенклатуры. В результате просчетов лидеров демократического движения представители советской номенклатуры достаточно быстро начали вытеснять из структур российской власти «демократов первой волны» и реформаторов «гайдаровского призыва», чтобы полностью овладеть рычагами управления государством. Этот процесс был проявлением более общего и фундаментального процесса размежевания демократического движения и формирующейся в качестве нового правящего слоя российской номенклатурой, которая являлась прямой наследницей номенклатуры советской. Переломным моментом, резко ускорившим процесс размежевания и отход российской номенклатуры от либеральных и демократических принципов модернизации страны, стала начавшаяся в конце 1994 года чеченская трагедия. При этом чеченские события не только окончательно развели российскую номенклатуру и демократическое движение, но и раскололи само демократической движение.

Ключевые слова: революционные преобразования, постсоветская Россия, демократическое движение, номенклатура, чеченский разлом

Для цитирования: Nisnevich Yu.A. The revolution is over, forget it: To the 30th anniversary of the Russian Federation // Вестник Российского университета дружбы народов. Серия: Политология. 2021. Т. 23. № 4. С. 545-559. DOI: 10.22363/2313-1438-2021-23-4-545-559

\section{Introduction}

The adoption of the Constitution of post-Soviet Russia via a referendum on December 12, 1993 marked the end of the revolutionary transformations in the country. These transformations can be traced back to the III Extraordinary Congress of People's Deputies on March 14, 1990, as it abolished Article 6 of the USSR Constitution in the wording, which established the monopoly on power of the Communist Party of the Soviet Union, declaring it "the leading and guiding force of the Soviet society and the nucleus of its political system, of all state and public organizations".

In full accordance with the modern theory of revolution, the revolutionary transformations of 1990-1993 were aimed at "transforming political institutions and giving a new justification for political power in the society" [Goldstone 2006, p. 61], which was legally enshrined by the 1993 Constitution. The new rationale for the political power in the society is determined by not only its new constitutionalization, but also the changes in the social structure and in the ruling social group or stratum. Significant changes in the social structure of the Russian society occurred as a result of the phenomenon of the "uprising of the Soviet masses" [Nisnevich 2018], while the issue of how the ruling stratum changed requires factual analysis.

\section{The democratic movement and the nomenclature}

Two different social groups acted as the driving forces of the revolutionary events of 1991-1993.

On the one hand, there was the relatively small, but active, democratically minded part of the Soviet society, mainly living in the two capitals and large 
scientific and industrial centers. This social group included mostly middle-aged people who, as a rule, were already on the rise or even at the top of the professional career available to them under the Soviet system. However, being Soviet romantics, they were willing to spend all of their energy and time on the protest movements for the sake of a "common bright future", even at the expense of their own careers. These passionaries were one in their revolutionary impulse, and were united in the common desire to destroy the Soviet wall, behind which there should be, though not very clear in what form, but certainly the best life for everyone.

On the other hand, there was the part of the Soviet party and economic nomenclature that possessed specific political, organizational and information resources. Under the aging Soviet regime and the gerontological ossification of the top of the nomenclature pyramid, they did not see real prospects for rapid career growth and advancement to the highest echelons of power. This progressiveminded part of the Soviet nomenclature, first of all, consisted of the middle and the lower - just beginning to climb up the career ladder - layers of the Soviet party and state bureaucracy. It was interested in the soonest elimination of the ossified upper ruling stratum and party leaders, as only this could provide its representatives with opportunities for accelerated career growth.

Thus, the social democratic movement and the progressives-minded part of the Soviet nomenclature acted as partners and allies in solving one common task changing the existing system of political and state administration, creating new political and state institutions. At the same time, they had significantly different views on the solution of this problem, as the subsequent development of the events showed.

As a result of the failure of the August 1991 putsch and the collapse of the USSR, the power in the now sovereign Russian state was seized by the conglomerate of the leaders of the democratic movement - the "first wave democrats", and the representatives of the progressive-minded Soviet nomenclature, primarily consisting of the party and state bureaucracy, headed by President Boris Yeltsin. At the initial stage of revolutionary transformations, this revolutionary conglomerate was supported by the part of the Russian society oriented towards democracy and market economy reforms, represented, above all, by its most massive social and political association - the Democratic Russia movement, created in 1990.

What played a decisive role in the formation of the ruling stratum of postcommunist Russia, was the tactical decision to staff practically all governmental bodies and structures with the officials who had previously worked in the state and party apparatus of the USSR and Soviet Russia. This was justified by the fact that such officials know the previous economic system better than anyone else, and therefore are able to quickly resume the work of the Russian government structures. This decision was made largely due to the time pressure - the need to relaunch the government mechanism as soon as possible, but in the long term, it had negative consequences - in terms of the quality of both the Russian public power and the overall post-revolutionary political process. Besides what was mentioned, the professionalism of the "specialists" from the Soviet party and economic 
nomenclature consisted, first of all, in mastering the methods of bureaucratic office work, behind-the-scenes decision-making, as well as the techniques of apparatus intrigues.

This situation was confirmed by Yegor Gaidar, who worked for the Russian government from November 6, 1991 (Deputy Chairman of the Government of the RSFSR, Minister of Economy and Finance) to December 14, 1992 (from June 16, 1992 - Acting Chairman of the Government of Russia). He later wrote in 1996 that the Chief of the Government Staff, Aleksey Golovkov, "was able to attract qualified, experienced employees from both the former Council of Ministers of the Union and the structures of the Russian government, and ensured that they really work on the preparation of regulations that ensure the implementation of reforms". And furthermore: "When you put your signature on documents in the government, you get the feeling of walking through a minefield. Under no circumstances you can completely rely on the apparatus... there were, of course, mistakes, but Alexei managed to neutralize the overwhelming majority of the "mines" before the paper was on my desk" [Gaidar 1996, p. 120-121]. Almost as Winston Churchill said" they themselves created a nomenclature "minefield", and then started heroically getting over it. It should be noted that President Boris Yeltsin gave a slightly different assessment of Golovkov's work: "A former junior researcher at the institute where Gaidar worked, Aleksey Golovkov became the head executive of the Council of Ministers, and this is a position that requires a strong grip and experience - purely administrative. As a result, the paperwork began to fall off to one side..." [Yeltsin 1994, 247].

Similar situations occurred at the regional level. For example, in Moscow, the new chairman of the Moscow City Council (Mossovet), Gavriil Popov, convinced the deputies of the "Democratic Russia" faction, which had a majority of 281 out of the 500 seats after the 1990 elections, to appoint the deputy chairman of the previous City Executive Committee, Yuri Luzhkov, to the post of the chairman of the new Moscow City Executive Committee (Mosgorispolkom), on the recommendation of President Boris Yeltsin. He motivated this by the fact that the democrats who have come to power will not be able to cope with the economic system of Moscow, and a person who knows this system from the inside is necessary. Later in June 1992, Popov voluntarily resigned from the post of the mayor and handed over his power to Luzhkov, which resulted in the well-known "crony capitalism".

The abovementioned political decision led to another the uprising of the Soviet masses, namely the "vertical invasion of the barbarians", in the words of German entrepreneur and politician Walter Rathenau [Ortega-i-Gasset 2003, p. 52], into the system of the public power of post-Soviet Russia, represented by the mass of the

\footnotetext{
${ }^{1}$ Winston Churchill's quote is known in two versions: "the Russians create difficulties for themselves and then heroically overcome them" and "Bolsheviks create difficulties for themselves and then overcome them brilliantly". Aphorisms. Quotes. Winged Words and Expressions. (In Russian). URL: http://www.bibliotekar.ru/encSlov/16/70.htm (accessed: 17.02.2021).
} 
Soviet nomenclature, the typological majority of whom was also the Soviet man. But at the same time, this kind of a Soviet man was even more characterized by limited self-sufficiency and aggressive rejection of everything alien and extraordinary, while striving by any means to seize the control button of the "miraculous machine of the state". Therefore, the representatives of the Soviet nomenclature quickly began to oust the "democrats of the first wave" and the reformers of the "Gaidar's call" from the structures of Russian power in order to gain full control over the levers of the government.

The exodus of the "first wave democrats" from the Russian governmental system began during the revolutionary transformations at the end of 1992. As a result of this process, such well-known People's Deputies of the USSR - members of the Inter-regional Deputies' Group, as Galina Starovoytova (November 1992), Eduard Burbulis (December 1992), Yuri Boldarev (March 1993), Sergei Stankevich (December 1993), Ella Pamfilova (March 1994), Alexey Kazannik (April 1994), Vladimir Smirnov (December 1994), as well as famous People's Deputies of the Russian Federation who were members of the "Democratic Russia" and "Radical Democrats" factions, Bela Denisenko (December 1992), Georgy Zadonsky (October 1993), Peter Filippov (April 1994), Sergey Kovalev (March 1995), Sergey Filatov (January 1996) and others left the upper echelons of the Russian government. Some representatives of the "first wave democrats" remained in the structures of the federal government, but either lost significant political influence or did not occupy the highest positions. Similar processes took place at the regional level. For instance, in November 1992, Arkady Murashev, a member of the Interregional Deputies' Group, was relieved of his post as the head of the Main Directorate of Internal Affairs of the City of Moscow. In April 1993, on charges of power abuse and corruption, the first and last President of the Mordovian SSR Vasily Guslyannikov - the co-chairman of the "Democratic Russia" movement, was dismissed of his post. In September of the same year, he was rehabilitated by the decision of the Penza Prosecutor's Office and cleared of all charges, but the president's post had already been abolished.

One of the reasons for this development of events was that the few representatives of the democratic movement, who were initially included in the power structures of post-Soviet Russia, relied only on the personal support by President Boris Yeltsin. They did not consider it necessary and did not pay much attention to strengthening the democratic movement as their long-term political support and personnel reserve to at least gradually replace the nomenclature. Therefore, the old nomenclature environment, which was partially new in its structure, but retained the main mechanisms of functioning in essence, rather quickly began displacing them from the power structures as alien elements both at the federal and regional levels.

Parallelly, the reformers of the "Gaidar call" were being excluded from the Government of the Russian Federation. The team of reformers suffered the first losses even before the resignation of Yegor Gaidar himself - Vladimir Lopukhin (May 1992), Andrey Vorobyov (October 1992), Eduard Dneprov (December 1992), 
as well as the already mentioned Gennady Burbulis (November 1992), who suggested President Boris Yeltsin including the team of the reformers led by Gaidar in the government. The exclusion of the reformers naturally intensified after, in December 1992, President Boris Yeltsin gave the post of the Chairman of the Russian Government to "strong economic manager" Viktor Chernomyrdin and not to the main ideologist of market reforms Yegor Gaidar. This decision was taken under the pressure from the Congress of People's Deputies of Russia. This resulted in inconsistency and a slowdown in the economic reforms, which gave rise to the joke that "the country paid a high price for Chernomyrdin's training in the fundamentals of market economy". After Gaidar's resignation, Petr Aven (December 1992), Boris Furmanov (December 1992), Andrey Nechaev (March 1993), Vasily Barchuk (March 1993), Ella Pamfilova (March 1994), as well as Vladimir Mashits (March 1995) left the government.

To complete the picture of the exodus of the reformers, it should be mentioned that Yegor Gaidar, at the suggestion of President Boris Yeltsin, returned to the government on September 18, 1993, taking the post of First Deputy Prime Minister of Russia. But Gaidar's second "coming" to the government was short, and as soon as in early 1994 he wrote a letter to the president asking for resignation, which was accepted on January 20. Gaidar substantiated his decision as follows: "As of January 1994, my ability to influence the process of making fundamental economic and political decisions was practically zero. ... By agreeing to remain in the government in a purely decorative role, I would simply demonstrate my readiness to join the cohort of people for whom the very fact of being in power or near is the main purpose" [Gaidar 1996, p. 318].

The process of ousting the "democrats of the first wave" and the reformers of the "Gaidar call" from the structures of Russian power was a manifestation of a more general and fundamental process, namely, the disengagement of the democratic movement (which at that time was a conglomerate of socio-political organizations of a democratic sense, scattered and significantly lacking influence), and the emergence of a new ruling stratum - the Russian nomenclature, which was the direct heir of the Soviet nomenclature ${ }^{2}$.

The Russian nomenclature, not yet fully consolidated, was intensively seizing the levers of governance, although its power remained chaotic and insufficiently stable, and those who opposed the nomenclature methods of governance still retained some influence in the immediate vicinity of President Boris Yeltsin. The Russian nomenclature, which is, in fact, a marginal social group and did not exceed $1-2 \%$ of the population of post-Soviet Russia in the mid-90s, became the leading force, determining and imposing the direction of political, economic and social transformations on Russian society. Therefore, the democratic movement, which had significantly lost its revolutionary fervour, social influence, fragmented and largely discredited not without the help of its temporary nomenclature fellows and

\footnotetext{
${ }^{2}$ On the formation and the development of the Russian nomenclature as a ruling social stratum, see: [Nisnevich 2015].
} 
political opponents, was no longer needed as a political ally for this nomenclature, which was oriented in the process of modernizing the country, first of all, to strengthen and to expand its own dominant position in the society and the state.

\section{The Chechen Rift}

The Chechen tragedy that began in late 1994 became the turning point that vastly accelerated the disengagement of the Russian nomenclature from the democratic movement and its departure from the liberal and democratic principles of modernizing the country. Yuli Rybakov, a deputy of the State Duma of I convocation from the "Choice of Russia" faction, expressed the opinion that: "In fact, the war in Chechnya is not only the tragedy of those who died there, it is the tragedy of the halted democratic process, which was interrupted by this war. There were quite clever people who realized that only a protracted war could stop the process of democratization in Russia, could stop the process of creating a civil society"3.

The first active actions around the events in Chechnya, contrary to the official position and statements of the current government, were undertaken by the deputies of the democratic "Choice of Russia" and "Yabloko" factions, even before Russian troops began entering Chechnya on December 11 of the same year.

The incentive for these actions was the assault on Grozny on November 26, 1994. The opposition to the president of the self-proclaimed Chechen Republic of Ichkeria (CRI) Dzhokhar Dudayev began an assault on Grozny, accompanied by several tanks, the crews of which consisted of Russian troops hired under a contract by the Federal Counterintelligence Service (FCS) ${ }^{4}$. The opposition was defeated. Although the tanks reached the city center without any problems, they were attacked using grenade launchers: many crew members were killed, dozens were captured. Russian Defense Minister Pavel Grachev publicly denied the participation of Russian troops in the assault, calling this version "nonsense". And, moreover, at a meeting with journalists on November 28, he said: "If the army was involved, then one airborne regiment would be enough to solve everything within two hours" [Dushenko 2020]. The representatives of the Ministry of Internal Affairs and the Federal Counterintelligence Service also denied their involvement in the Grozny events.

In the course of these events on December 1-3, deputies of the "Choice of Russia" and "Yabloko" factions were observing the bombing of Grozny on planes without identification marks. The deputies held negotiations with Dudayev, where an agreement was reached on the release of the prisoners. The deputies took two of

\footnotetext{
${ }^{3}$ Kara-Murza, V. Recalling the beginning of the invasion of the federal troops into Chechnya on the 15th anniversary of the tragic events with its eyewitnesses - former State Duma deputies Valery Borshchev and Yuliy Rybakov, 2009. (In Russian). URL: https://www.svoboda.org/a/1902090.html (accessed: 17.02.2021).

${ }^{4}$ Hereinafter, the information about the events in Chechnya is take from [Russia - Chechnya: a chain of mistakes and crimes].
} 
those freed from captivity to Moscow, where they were presented at a press conference by the chairman of the State Duma Defense Committee Sergei Yushenkov ("Choice of Russia" faction). Further, on December 3-6, a group of deputies of the LDPR faction headed by Yevgeny Loginov visited Grozny. As a result, the authorities of the CRI released two more prisoners. On the night of December 5-6, after the news of a planned military operation, deputies of the "Yabloko" and "Choice of Russia" factions, including Grigory Yavlinsky and Sergei Yushenkov, flew to Grozny and offered Dudayev to stay in Grozny in exchange for the release of the prisoners, in an attempt to prevent the assault. The proposal was rejected, but on December 7 , seven more prisoners of war were handed over to the deputies.

On the day after the publication of the Decree of the President of the Russian Federation No. 2166 of December 9, 1994 "On Measures to Stop the Activities of Illegal Armed Formations on the Territory of the Chechen Republic and in the Zone of the Ossetian-Ingush Conflict", which legally paved the way for the invasion of the Russian troops into Chechnya, the "Democratic Choice of Russia" party made a statement. The party stated: "The military action will result in numerous casualties among our soldiers and officers, and many times more casualties among the inhabitants of Chechnya. Including the Russians, whose safety the Russian leadership claims to care about. The result will be guerrilla war, an endless stream of coffins and burials from the Caucasus to Russia, and new military echelons from Russia to the Caucasus. The result will be a new Afghanistan. We are convinced that everything that has happened in recent weeks in Chechnya is not only the result of professional incompetence and a lack of elementary decency. We are sure that this is a deliberate provocation. ... Today the fate of our country is being decided. Will democratic reforms be continued, or will the country once again fall under the rule of a cruel and worthless dictatorship? ... We strongly condemn the actions of the federal authorities in Chechnya. ... We demand that the President and the Supreme Commander-in-Chief take immediate measures to prevent the war" ${ }^{\text {. }}$.

After the military operation in Chechnya was announced, democratic political parties and associations tried to organize mass protests, but this undertaking was not very successful. As Yegor Gaidar writes: "We are holding a rally on Pushkin Square, then on Teatralnaya Square. A bitter feeling is overwhelming: there is no necessary public support. Yes, a lot of people do not like the war, but they also do not like the Dudayev regime, there is no understanding of what a huge disaster, what terrible blood all this will turn into. Some people sincerely believe that everything will be over in a few days. As my DCR (the Democratic Choice of Russia) colleague Sergei Yushenkov exactly stated, the society is to blame for not opposing the war decisively enough, and this encouraged the authorities to take adventurous actions" [Gaidar 1996, p. 332].

\footnotetext{
${ }^{5}$ Statement by the Democratic Choice of Russia party of 10.12.1994. Yegor Gaidar's archive. Database of documents. URL: http://gaidar-arc.ru/file/bulletin-1/DEFAULT/org.stretto.plugins.bulletin.core.Article/file/3636 (accessed: 17.02.2021).
} 
This situation is likely to be explained by the fact that, although according to the results of sociological research $\sim 55 \%$ of Russian citizens reacted negatively to the use of the armed forces to resolve the situation in Chechnya, after the events of the fall of 1993 the Russian society fell into deep political apathy and did not believe that it could influence the Government's decisions and actions.

At the same time, many well-known public figures, human rights activists, writers and journalists actively and publicly expressed their protest against the invasion of the Russian troops to Chechnya. In December 1994, a prominent member of the human rights movement in the USSR, Kronid Lyubarsky, left the Public Chamber under the President of the Russian Federation, and writer and publicist Karjakin left the Presidential Council. Karjakin, in his characteristic sharp manner, told the president at a council meeting: "It is not so much about your suicide, to which you are being pushed - we are talking about the suicide of the democracy, and of Russia - this is what they are actually pushing you toward" [Koryakin, 2007].

In January 1995, legal scholar, one of the "fathers" of the 1993 Constitution, Sergei Alekseev, publicist Otto Latsis and Gaidar left the Presidential Council. The widow and colleague of Academician Sakharov, Elena Bonner, left the Commission on Human Rights under the President of the Russian Federation, bluntly stating that she did not consider it possible for herself to cooperate with the presidential administration, which unleashed the Russian-Chechen war. Together with members of the commission Vyacheslav Bakhmin, Igor Golembiovsky, Boris Zolotukhin and Sergei Sirotkin she wrote an official statement about leaving the commission. This happened after an open letter from Sergei Kovalev to President Yeltsin was published in the Izvestia newspaper on January 24, 1996, in which he announced his resignation from the post of the Chairman of the Commission on Human Rights, and his resignation from the Presidential Council ${ }^{6}$. The well-known jurist Yuri Kalmykov resigned from the posts of the Minister of Justice and the member of the Security Council even before the start of the Chechen operation, on November 29, 1994: at the meeting of the Security Council, he was the only Council member who opposed the invasion ${ }^{7}$. His resignation was accepted by the President on December 7, 1994. In protest, the editor-in-chief of the "Moscow Daily News" newspaper, Viktor Loshak, withdrew his signature from the April 1994 Agreement on Public Accord.

The democratic media was also actively opposing a military solution to the Chechen problem. Oleg Poptsov, at that time the chairman of the All-Russian State Television and Radio Company, recalled: "The greatest surprise for the President, a kind of revelation, was the reaction of the democratic press, which in its overwhelming majority was hostile to the military actions in Chechnya.

\footnotetext{
${ }^{6}$ Presidential Council for Human Rights: The Art of the Impossible. Presidential Council for Civil Society and Human Rights. (In Russian). URL: http://www.president-sovet.ru/projects/books/read/8/ (accessed: 17.02.2021).

${ }^{7}$ Kobrin, K. (2004). Ivan Rybkin recalls the meeting of the Russian Security Council on November 29, 1994. (In Russian). URL: https://www.svoboda.org/a/24185286.html (accessed: 17.02.2021).
} 
Newspapers, radio, television, also taken by surprise, vied to talk about the danger of civil, Caucasian, partisan wars, the destabilization of the economic situation, inevitable losses among the civilian population, the fanatical resistance of the Chechens, and the futility of a military solution to the problem" [Poptsov 1995].

From the very beginning, Russian troops began to suffer significant losses in manpower and equipment due to the lack of necessary professional training of soldiers and officers and proper organization of the military operation. Defense Minister Grachev's statement that "one airborne regiment would be enough to solve everything within two hours", naturally, turned out to be a bluff. Discontent began to appear in the top commanding staff, and on December 15, 1994, Defense Minister Grachev removed a group of senior officers who were refusing to send troops to Chechnya and expressing a desire to receive a written order from the Supreme Commander-in-Chief "before starting a major military operation that could entail great casualties among the civilian population". In December 1994, the Deputy Commander-in-Chief of the Ground Forces, Colonel-General Eduard Vorobyov, did not take command of the operation in Chechnya "due to its complete unpreparedness" and filed a letter of resignation. Subsequently, General Vorobyov became a member of the Political Council of the DCR party and in December 1995 was elected from this party as a deputy of the State Duma of the second convocation.

It should be noted that on December 13, 1994, the State Duma adopted Resolution No. 385-I GD "On the situation in the Chechen Republic, a subject of the Russian Federation, and measures for its political settlement". This resolution recognized "the work of the President of the Russian Federation and federal government bodies on the political settlement of the explosive situation in the Chechen Republic as unsatisfactory" and made "a proposal to the warring parties in the Chechen Republic to stop the bloodshed and solve all existing problems exclusively by peaceful means." On December 17, the Federation Council adopted Resolution No. 307-I FC "On the Situation in the Chechen Republic," which proposed "to the President of the Russian Federation to take measures for an immediate cessation of hostilities by all parties and to continue the negotiation process at a higher level of government delegations based on the principles of preserving the integrity of the Russian Federation and providing the people of the Chechen Republic with the possibility of free expression of their will."

The anti-war activities of the democratic factions of the State Duma, whose deputies regularly traveled to Chechnya, was directed precisely at ending hostilities and organizing negotiations.

The unauthorized peacekeeping activities of the deputies, but especially the information they provided about the real state of affairs in Chechnya, about the unprofessionalism and unpreparedness of the military operation, losses among Russian servicemen and civilians, which disavowed official messages, caused the discontent and irritation of the people in powers and, above all, the heads of the military structures. This resulted in intensified disagreements between the current government and the reformist-democratic political flank, as well as the democratically-minded minority of the Russian society. 
These disagreements were used by the anti-reformist flank in the State Duma. On March 10, 1995, on the initiative of the Communist and LDPR factions, as well as the deputies of the unregistered "patriotic" group "Russian Way" (Sergei Baburin and others), Sergei Kovalev, who headed the group of deputies that began working in Grozny on December 15, 1994, was removed from the position of the Commissioner for Human Rights. 240 votes were cast against him, which meant that the initiative was supported by a number of centrist deputies who, as the political structure of the lower house began to transform, reoriented to support the current government.

The appeals of the Russian Parliament and the democratic public to the leaders of Russia and the unrecognized CRI to stop hostilities and sit down at the negotiating table did not yield any results. Although the parties periodically declared their readiness for negotiations, since they had different understanding of the meaning and the content of these, no really significant negotiations were held. For example, on December 23, 1994, Russian Foreign Minister Andrei Kozyrev in a telephone conversation asked the Ombudsman for Human Rights Sergei Kovalev, who was in Grozny, to find out the Chechen leadership's conditions to start negotiations with Moscow. Kovalev contacted Dudayev, who announced his readiness for an immediate bilateral cessation of hostilities and the start of negotiations on the entire spectrum of controversial issues, including the disarming his formations. In the evening of the same day, Kovalev reported this to Kozyrev, who promised to report on Grozny's readiness for negotiations at a meeting of the Security Council of the Russian Federation. However, no reaction from Moscow followed.

At the same time, Russian troops, despite heavy losses both among the military and the civilian population, continued to advance deeper into the territory of Chechnya and take control of its cities and towns. Under these conditions, the armed detachments of the separatists, as predicted, switched to the tactics of partisan, sabotage, subversive and terrorist actions, including outside Chechnya.

On June 14, 1995, the detachment of warlord Shamil Basayev penetrated into the city of Budyonnovsk, Stavropol region, and captured more than one and a half thousand hostages, who were held in the hospital of the city. At dawn on June 17, special forces of the Ministry of Internal Affairs and the FSB of Russia made several unsuccessful attempts to storm the hospital, leaving casualties among both the terrorists and the special forces, but the hostages suffered the most - up to 30 dead, many wounded.

On the eve of this assault on June 16, the "Kovalev group" arrived in Budyonnovsk on its own initiative. The group included, besides Sergei Kovalev himself, State Duma deputies Valery Borschov, Mikhail Molostvov, Alexander Osovtsov, Yuliy Rybakov, Federation Council member Viktor Kurochkin and representative of "Memorial" Oleg Orlov. Only after the assault failed, did the "Kovalev group" manage to agree with the Russian authorities (which at that moment were represented by Prime Minister Viktor Chernomyrdin, since President Boris Yeltsin flew to Canada for the G7 summit on June 16) on coordinated joint actions. Viktor Chernomyrdin gave the "Kovalev group" powers to negotiate with 
Basayev. As Oleg Orlov testifies: "In the early morning of June 18, Sergei Kovalev and the members of his group, with the consent of both sides, entered the hospital and began negotiations with Shamil Basayev on the conditions for the release of the hostages. Within two hours, Basayev was persuaded to abandon the obviously impracticable condition - the immediate withdrawal of Russian troops from the southern regions of Chechnya - and to agree on the main provisions of the agreement on the release of the hostages. Then, through the mediation of Kovalev, a telephone conversation was organized between Viktor Chernomyrdin and Shamil Basayev $^{8}$, who agreed on the final conditions for the release of the hostages: the cessation of hostilities on the territory of Chechnya and the subsequent resolution of all controversial issues through negotiations. These provisions were recorded in writing on the morning of June 18, 1995 in two documents, written in the same place, in the hospital, by hand, on notebook sheets. The original copies of these documents are kept in the archives of "Memorial".

The next day, June 19, Basayev's detachment, under the cover of a "human shield" of 120 hostages, including the members of the "Kovalev group" and journalists, left Budyonnovsk for Chechnya on buses provided by the Russian side. On June 20, a column of buses arrived in the Chechen village of Zandak, which was under the control of the separatists, where all the hostages were released. According to the Russian FSB Directorate for the Stavropol Krai, the terrorist act in Budyonnovsk resulted in 129 people dead, including 18 militiamen and 17 military personnel. 415 people received gunshot injuries. The release of the hostages in Budyonnovsk was the first and perhaps the only example during the first Chechen war of how the joint actions of the Russian authorities and the representatives of the democratic movement led to a positive result - the rescue of most of the hostages.

The Chechen events not only further tore apart the current government, or rather the emerging ruling stratum - the Russian nomenclature and the democratic movement, but also split the democratic movement itself.

Such political organizations, initially related to the reformist-democratic flank, as the "Choice of Russia" and "Forward, Russia!" movements supported the invasion of Chechnya. While some of the regional branches of the "Choice of Russia" did not support the position of their leadership, on December 22, 1994 the leader of the "Forward, Russia!" Boris Fedorov announced his unequivocal support for a military solution to the Chechen problem in Vladislav Listyev's TV program "The Rush Hour" on the ORT TV Channel ${ }^{10}$.

\footnotetext{
${ }^{8} \mathrm{~A}$ fragment of this conversation, broadcast live on television throughout the country, see: URL: https://www.youtube.com/watch? $\mathrm{v}=165 \mathrm{v} 3 \mathrm{ZsPQPo}$ (accessed: 17.02.2021).

${ }^{9}$ Orlov, O. (2015). The Release of the Hostages in Budennovsk: Documents. Program: Hot spots. Echo of Moscow. 28 August. (In Russian). URL: https://memohrc.org/ru/blogs/osvobozhdenie-zalozhnikov-v-budennovske-dokumenty (accessed: 17.02.2021).

${ }^{10}$ The Rush Hour with Boris Fedorov, December 22, 1994. (In Russian). URL: https://www.warchechnya.ru/load/video_o_vojne_v_chechne_smotret_on_lajn/chas_pik_s_borisom_fedorovym_22_dekabrja_1994/6-1-0-955 (accessed: 17.02.2021).
} 
Serious disagreements arose in the DCR party as well. Here is how its chairman Yegor Gaidar describes the situation in his party: "For the DCR, the Chechen war turned into a very difficult internal demarcation line. The party was created as liberal, close to democratic power. There are many people in it who are truly committed to democratic convictions, but there are also many people who have come to support the power that is more or less acceptable to them. I understand that the events in Chechnya are a source of an inevitable split. The liberals will stay with us. Those who came to the party of power will look for another political shore" [Gaidar 1996, p. 322].

By the beginning of the Chechen war, two positions had developed in the leadership of the DCR party: the first position, expressed by Sergei Yushenkov, was to speak out sharply against the military operation in Chechnya and oppose the president; the second or the "conciliatory" position, expressed by the chairman of the Moscow city organization of the party Sergei Blagovolin, was to oppose the methods of the implementation of the military solution to the Chechen problem, but to preserve the possibility of dialogue with the authorities. As a result, the DCR party moved into opposition to the current government, albeit in a rather specific form, since it continued to support any reforms of the government, especially in the economic sphere. Naturally, the supporters of the interactions with the government began to leave the party. In particular, Blagovolin, as well as the chairman of the party executive committee, entrepreneur Oleg Boyko and other supporters of the "conciliatory", but essentially pro-government position, left the party.

A split also occurred in the "Choice of Russia" faction of the State Duma. Those who, driven by their personal political interests, were leaning towards joining the "party of power" or, at least, active interactions with the authorities, began to leave the faction. A typical example is Foreign Minister Andrei Kozyrev, who supported the military solution to the Chechen problem and left the faction in December 1994. In February 1995, the faction's deputy chairman, Aleksey Aleksandrov, and one of the co-chairs of the "Choice of Russia" movement, Aleksey Golovkov, who had previously been Yegor Gaidar's closest associate in the government, left the faction. These "defectors" started to create new pro-government parliamentary groups "Russia" and "Stability", and began to recruit the deputies, who left the "Choice of Russia" faction. After these groups were registered, in March 1995, the "Choice of Russia" faction was reduced to 55 people.

\section{Conclusion}

The Chechen tragedy led to the Russian political space splitting into three fractions ("localities"), separated from one another by ideological and value cracks of different depth and width.

The first political locality was constituted by the not yet fully formed and incompletely consolidated "party of power", where the representatives of power structures began to be promoted to leading positions. This, in particular, was evidenced by the incumbent government's course at strengthening and providing material support to the power structures, as later shown by the deputy of the State 
Duma of the first three convocations Vladimir Golovlev when analyzing the budget process in the State Duma of the second convocation (1995-1999) [Golovlev, Nefedova, 2000, pp. 129-139].

A rather deep and wide ideological and value gap separated the locality of the "party in power" from the anti-reform locality dominated by the Communist Party of Russia and the Liberal Democratic Party. These parties periodically publicly confronted not only the current government, but also each other. However, these confrontations never had far-reaching political consequences and often had a momentary, demonstrative character.

On the other hand, the ideological and value gap, which began to gradually expand and deepen, started alienating the reformist-democratic locality from the locality of the "party of power". This locality, which, due to both objective and subjective reasons, was melting like an iceberg in the turbulent stream of the Russian political life, was dominated by the DCR party and the "Yabloko" association: the not always fundamental ideological and value differences, that existed between these two forces, constantly prevented them from uniting for joint political action.

The Chechen tragedy obviously accelerated the process of the formation and the consolidation of the Russian nomenclature, which was rooted in the Soviet party and economic nomenclature and became the ruling social stratum in post-Soviet Russia. Thus, according to the results of the research of the IS RAS published in 1996 , more than $75 \%$ of the Russian political and $61 \%$ of the business elite came from the Soviet nomenclature [Khenkin 1997, p. 29].

Received / Поступила в редакцию: 10.06.2021 Accepted / Принята к публикации: 15.08.2021

\section{References / Библиографический список}

Dushenko, K. (2020). Quotes from Russian history. From the vocation of the Varangians to the present day. Litres. (In Russian).

Душенко К. Цитаты из русской истории. От призвания варягов до наших дней: справочник [Электронная книга]. Издательство Litres, 2000.

Gaidar, E.T. (1996). Days of defeat and victory. Moscow: Vagrius. (In Russian).

Гайдар Е.T. Дни поражений и побед. М.: ВАГРИУС, 1996.

Goldstone, J. (2006). Toward a Fourth Generation of Revolutionary Theory. Logos, (5), 58-103. (In Russian).

Глодстоун Д. К теории революции четвертого поколения // Логос. 2006. № 5 (56). С. 58-103.

Golovlev, V.I., \& Nefedova, T.I. (2000). State Duma Second Convocation: Role and Place In Political Turn. Moscow: Noosfera Foundation. (In Russian).

Головлев В.И., Нефедова Т.И. Государственная Дума второго созыва: роль и место в политическом переломе. М.: Фонд «Ноосфера», 2000.

Khenkin, S.M. (1997). "Party of Power": Touches to the Portrait. Politeia, 1, 28-35. (In Russian). Хенкин С.M. «Партия власти»: штрихи к портрету // Полития. 1997. № 1. С. 28-35.

Koryakin, Y. (2007). Change of beliefs (From the "Diary of a Russian reader"). Znamya Magazine. № 11. Retrieved February 17, 2021, from http://znamlit.ru/publication.php?id=3420. (In Russian). 
Корякин Ю. Перемена убеждений (Из «Дневника русского читателя») // Журнал «Знамя». (2007) № 11. URL: http://znamlit.ru/publication.php?id=3420 (дата обращения: 17.02.2021). Nisnevich, Yu.A. (2015). Regeneration of the nomenclature as a ruling social order. Preprint WP14/2015/03. Moscow: HSE Publishing House. (In Russian).

Нисневич Ю.А. Регенерация номенклатуры как правящего социального строя. Препринт WP14/2015/03. М.: Издательский дом Высшей школы экономики, 2015.

Nisnevich, Yu.A. (2018). The revolt of the soviet masses: political and anthropological analysis. Public Sciences and Contemporary World, 2, 127-139. (In Russian).

Нисневич Ю.А. Восстание советских масс: политико-антропологический анализ // Общественные науки и современности. 2018. № 2. С. 127-139.

Orlov, O.P., \& Cherkasov, A.V. (Eds.). (1998). Russia - Chechnya: a chain of mistakes and crimes. Moscow: Zvenya. Retrieved February 17, 2021, from https://memohrc.org/ru/books/rossiyachechnya-cep-oshibok-i-prestupleniy (In Russian).

Россия - Чечня: цепь ошибок и преступлений / сост. О.П. Орлов, А.В. Черкасов. М.: Звенья, 1998. URL: https://memohrc.org/ru/books/rossiya-chechnya-cep-oshibok-i-prestupleniy (дата обращения: 17.02.2021).

Ortega-i-Gasset, J. (2003). The Revolt of the Masses. Moscow: AST Publishers. (In Russian). Opmeга-и-Гассет X. Восстание масс. М.: АСТ, 2003.

Poptsov, O. (1995). Chronicle of the Times of "Tsar Boris". Moscow: Top Secret. (In Russian). Попщов О. Хроника времен «Царя Бориса». М.: Совершенно секретно, 1995.

Yeltsin, B. (1994). Notes of the President. Moscow: Ogonek Publishing House. (In Russian). Ельцин Б. Записки президента. М.: Издательство «Огонек», 1994.

\section{About the author:}

Yuliy A. Nisnevich - Full Professor, Doctor of Political Science, professor, Department of Politics and Governance, National Research University Higher School of Economics (e-mail: jnisnevich@hse.ru) (ORCID: 0000-0001-9911-9623)

\section{Сведения об авторе:}

Нисневич Юлий Анатольевич - доктор политических наук, профессор департамента политики и управления Национального исследовательского университета «Высшая школа экономики» (e-mail: jnisnevich@hse.ru) (ORCID: 0000-0001-9911-9623) 